\title{
PEMAHAMAN DAN DUKUNGAN SUAMI TERHADAP KEIKUTSERTAAN IBU MENJADI AKSEPTOR KB IUD DI KECAMATAN SECANGGANG LANGKAT
}

\author{
Dewi Rismauli Bancin ${ }^{1)}$, Friska Sitorus ${ }^{2)}$, Surya Anita ${ }^{3)}$ Ade Bayu Hartati ${ }^{4)}$ \\ Fakultas Farmasi dan Ilmu Kesehatan, Universitas Sari Mutiara Indonesia \\ email: dewi_bancin@ymail.com
}

\begin{abstract}
The decrease in TFR (Total Fertility Rate) will be closer to the condition of the population growing in balance, a strategy is needed in the implementation of the family planning program. Activities that can be carried out are promoting long-term effective contraceptive methods. This study aims to determine the understanding and support of husbands for the participation of mothers in becoming IUD KB acceptors in Secanggang District, Langkat Regency. The research design used in this study was an analytical survey with cross sectional approach. The sample in this study was 30 respondents who came and wanted to do family planning. The data analysis used was univariate and bivariate analysis. The results of this study indicate that there is a significant relationship between Husband's understanding of the participation of mothers in becoming IUD family planning acceptors in Secanggang District, Langkat Regency, with a pvalue of 0.000. And there is a significant relationship between the husband's support for the participation of mothers in becoming IUD family planning acceptors in Secanggang District, Langkat Regency with a p value of 0,02 and And there is a significant relationship between the husband's support for the participation of mothers in becoming IUD family planning acceptors in Teluk Village, Secanggang District, Langkat Regency with a p value of 0,02. It is hoped that it can increase respondents' knowledge about contraceptives so that they can support and understand their wives in choosing contraceptives.
\end{abstract}

Keywords: Understanding, Support, IUD

\section{PENDAHULUAN}

Program KB adalah bagian yang terpadu (integral) dalam pembangunan nasional dan bertujuan untuk menciptakan kesejahteraan ekonomi, spiritual dan sosial budaya penduduk Indonesia agar dapat dicapai keseimbangan yang baik dengan kemampuan produksi nasional.Tujuan program keluarga berencana adalah menciptakan keluarga kecil yang bahagia dan sejahtera sedangkan sasaran program KB yaitu pasangan usia subur (sasaran langsung) dan pelaksana dan pengelola program KB (sasaran tidak langsung). (Handayani, 2016)

IUD adalah metode kontrasepsi darurat yang paling efektif. Pada Penelitian yang di lakukan di Amerika Serikat menunjukkan bahwa $85 \%$ dari dokter tidak pernah merekomendasikan IUD untuk kontrasepsi darurat dan $93 \%$ membutuhkan setidaknya dua kunjungan untuk pemasangan AKDR. (Koes, 2013)

Indonesia merupakan salah satu peserta dari pertemuan di Alma Ata pada tahun 1978 yang diselenggarakan oleh $W H O$ dan
UNICEF.Dalam pertemuan tersebut disepakati upaya untuk menurunkan angka kematian ibu dan bayi dengan menetapkan konsep Primary Health Care yang termasuk di dalamnya adalah upaya penerimaan keluarga berencana. Sejak saat itu berbagai upaya telah dilakukan pemerintah dalam mensukseskan program KB di Indonesia dengan kebijakan yang dilakukan secara bertahap.(Handayani,2016)

Penurunan TFR (Total Fertility Rate) akan lebih mendekati kondisi penduduk tumbuh seimbang diperlukan suatu strategi dalam pelaksanaan program keluarga berencana. Kegiatan yang dapat dilaksanakan yaitu dengan mempromosikan metode kontrasepsi efektif jangka panjang. Hal tersebut berlawanan dengan kondisi saat ini, pemakaian metode kontrasepi efektif jangka panjang khususnya IUD relatif mengalami penurunan sedangkan penggunaan metode kontrasepsi hormonal seperti suntik mendominasi dari pemakaian kontrasepsi.(Anggara, 2015) 
Menurut World Health Organization (WHO), KB adalah suatu tindakan yang membantu individu atau pasangan suami istri untuk mendapatkan kelahiran yang diinginkan, menghindari kelahiran yang tidak diinginkan, mengatur interval diantara kehamilan, dan menentukan jumlah anak dalam keluarga, salah satu program $\mathrm{KB}$ adalah penggunaan alat kontrasepsi. Penggunaan kontrasepsi di dunia pada 2015 sekitar 64\% pada perempuan menikah dan usia reproduksi, sedangkan penggunaan alat kontrasepsi di Afrika sekitar $33 \%$, Oseania sekitar 59\%, Amerika Utara sekitar 75\%, Cina 84\%, Indoneisa 65\%, dan Asia 57\%.7 Prevalensi penggunaan metode kontrasepsi bervariasi di dunia, kontrasepsi IUD $19 \%$, MOW 14\%, pil 9\%, kondom 5\%, dan suntik $6 \%$. Penggunaan metode jangka pendek seperti pil, suntik, dan kondom paling banyak digunakan di Afrika, Eropa, Amerika dan Oseania, sedangkan metode jangka panjang seperti MOW, implant, IUD lebih banyak digunakan di Asia dan Amerika Utara.(Suherman, 2017)

Berdasarkan survei awal yang dilakukan peneliti di Kecamatan Secanggang Kabupaten Langkat terdapat 60 akseptor KB dimana yang menggunakan KB suntik sebanyak 36 orang, pil sebanyak 14 orang, implant sebanyak 6 orang, dan IUD sebanyak 4 orang. Dari hasil wawancara yang dilakukan peneliti kepada 12 akseptor KB dimana yang menggunakan KB suntik 4 orang, pil 3 orang, implant 3 orang, dan pengguna IUD sebanyak 2 orang. Ibu yang tidak memakai kontrasepsi IUD mengatakan takut untuk memakai kontrasepsi IUD karena alat pemasangannya, ibu cemas nantinya benang IUD nya keluar, kemudian takut tempat pemasangan tidak tepat, serta suami tidak ada dukungan karena suami merasa tidak nyaman saat berhubungan badan.

\section{METODE PENELITIAN}

Desain penelitian yang digunakan dalam penelitian ini adalah survei analitik dengan pendekatan cross sectional.

Penelitian ini dilaksanakan di Kecamatan Secanggang Kabupaten Langkat, alasan pemilihan lokasi ini dikeranakan sangat sedikit ibu-ibu yang bersedia menjadi akseptor KB IUD.

Sampel dalam penelitian ini diambil secara total sampling dimana peneliti akan mengambil sampel sebanyak 30 responden yang datang dan ingin melakukan KB.

Analisa data menggunakan analisa univariate dan bivariate. Analisa univariate digunakan untuk mendeskripsikan distribusi frekuensi karakteristik responden, analisis bivariate untuk melihat pengaruh pemahaman dan dukungan suami.

\section{HASIL DAN PEMBAHASAN}

Penelitian tentang Pemahaman dan Dungngan Suami Terhadap Keikutsertaan Ibu Menjadi Akseptor KB IUD di Kecamatan Secanggang Kabupaten Langkat telah dilaksanakan. Sampel dalam penelitian ini adalah seluruh suami dari ibu yang aktif memakai alat kontrasepsi di wilayah kerja puskesmas Desa Teluk Kabupaten Langkat sebanyak 30 orang. Setelah data terkumpul, maka data diolah dan dianalisis. Data kemudian disajikan dalam bentuk tabel distribusi frekuensi dan beserta analisa data.

Tabel 1 Karakteristik Responden

\begin{tabular}{|c|c|c|}
\hline $\begin{array}{l}\text { Karakteristik } \\
\text { Responden }\end{array}$ & $\mathbf{N}$ & $\%$ \\
\hline \multicolumn{3}{|l|}{ Umur Istri } \\
\hline $20-27$ Tahun & 14 & 46,6 \\
\hline 28 -34 Tahun & 13 & 43,4 \\
\hline $35-41$ Tahun & 3 & 10,0 \\
\hline \multicolumn{3}{|l|}{ Umur Suami } \\
\hline $20-27$ Tahun & 14 & 46,6 \\
\hline $28-34$ Tahun & 13 & 43,4 \\
\hline $35-41$ Tahun & 3 & 10,0 \\
\hline \multicolumn{3}{|l|}{ Jumlah Anak } \\
\hline 1 ( Satu ) & 8 & 26,7 \\
\hline 2 ( Dua ) & 12 & 40,0 \\
\hline 3 ( Tiga ) & 7 & 23,3 \\
\hline 4 ( Empat ) & 3 & 10,0 \\
\hline \multicolumn{3}{|l|}{ Pekerjaan Suami } \\
\hline Bertani & 8 & 26,7 \\
\hline Wiraswasta & 12 & 40,0 \\
\hline PNS & 4 & 13,3 \\
\hline Pegawai Swasta & 6 & 20,0 \\
\hline \multicolumn{3}{|c|}{ Pendidikan Suami } \\
\hline Pendidikan Atas & 12 & 40 \\
\hline Pendidikan & 18 & 60 \\
\hline \multicolumn{3}{|l|}{ Tinggi } \\
\hline
\end{tabular}


mayoritas berusia 20 - 27 tahun sebanyak 14 orang (46,6\%), jumlah anak mayoritas mempunyai anak 2 sebanyak 12 orang $(40,0 \%)$, pekerjaan suami mayoritas wiraswasta sebanyak 12 orang $(40,0 \%)$, Pendidikan Tinggi sebnayak 18 orang $(60 \%)$.

Tabel 2. Pemahaman Suami Terhadap Keikutsertaan Ibu Menjadi Akseptor KB IUD

\begin{tabular}{|c|c|c|c|c|c|c|c|}
\hline \multirow{3}{*}{$\begin{array}{c}\text { Pemaha } \\
\text { man } \\
\text { Suami }\end{array}$} & \multicolumn{4}{|c|}{ Pemilihan IUD } & \multirow{2}{*}{\multicolumn{2}{|c|}{ Total }} & \multirow{3}{*}{$\begin{array}{l}P- \\
\text { Val } \\
\text { ue }\end{array}$} \\
\hline & \multicolumn{2}{|c|}{ Memilih } & \multicolumn{2}{|c|}{$\begin{array}{c}\text { Tidak } \\
\text { Memilih }\end{array}$} & & & \\
\hline & $\mathbf{F}$ & $\%$ & $\mathbf{F}$ & $\%$ & $\mathbf{F}$ & $\%$ & \\
\hline Paham & 19 & 63.3 & 1 & 3.3 & 20 & 66,7 & \\
\hline $\begin{array}{l}\text { Tidak } \\
\text { Paham }\end{array}$ & 0 & 0.0 & 10 & 33.3 & 10 & 33.3 & 0,00 \\
\hline Total & 19 & 63.3 & 11 & 45,6 & 30 & 100 & \\
\hline
\end{tabular}

menggunakan uji chisquare, diperoleh hasil perhitungan $\mathrm{p}$ value $=0,00<\alpha=0,05$, maka terdapat pengaruh pemahaman suami terhadap keikutsertaan ibu menjadi akseptor KB IUD.

Tabel 3. Dukungan Suami Terhadap Keikutsertaan Ibu Menjadi Akseptor KB IUD

\begin{tabular}{|c|c|c|c|c|c|c|c|}
\hline \multirow{3}{*}{$\begin{array}{l}\text { Dukun } \\
\text { gan } \\
\text { Suami }\end{array}$} & \multicolumn{4}{|c|}{ Pemilihan IUD } & \multirow{2}{*}{\multicolumn{2}{|c|}{ Total }} & \\
\hline & \multicolumn{2}{|c|}{ Memilih } & \multicolumn{2}{|c|}{$\begin{array}{c}\text { Tidak } \\
\text { Memilih }\end{array}$} & & & $\begin{array}{c}P- \\
\text { Val }\end{array}$ \\
\hline & $\mathrm{F}$ & $\%$ & $\mathrm{~F}$ & $\%$ & $\mathrm{~F}$ & $\%$ & \\
\hline $\begin{array}{l}\text { Mendu } \\
\text { kung }\end{array}$ & 11 & 40 & 7 & 20 & 18 & 60 & \\
\hline $\begin{array}{l}\text { Tidak } \\
\text { Mendu } \\
\text { kung }\end{array}$ & 9 & 20 & 3 & 10 & 12 & 40 & 0,02 \\
\hline Total & 20 & 66,6 & 10 & 33,3 & 30 & 100 & \\
\hline
\end{tabular}

menggunakan uji chisquare, diperoleh hasil perhitungan $\mathrm{p}$ value $=0,02<\alpha=0,05$, maka terdapat pengaruh dukungan suami terhadap keikutsertaan ibu menjadi akseptor KB IUD

Pemahaman merupakan salah satu patokan kompetensi yang dicapai setelah melakukan kegiatan belajar. Dalam proses pembelajaran, setiap individu memiliki kemampuan yang berbeda-beda dalam memahami apa yang dia pelajari. Ada yang mampu memahami materi secara menyeluruh dan ada pula yang sama sekali tidak dapat mengambil makna dari apa yang telah dia pelajari, sehingga yang dicapai hanya sebatas mengetahui. Untuk itulah terdapat tingkatan-tingkatan dalam memahami .

Faktor yang mempengaruhi pemahaman suami terhadap alat kontrasepsi yaitu tingkat pengetahuan, faktor pendidikan, faktor spiritual, praktik di keluarga, tingkat sosial ekonomi dan faktor latar belakang budaya. Menurut asumsi peneliti bahwa adanya pemahaman suami pada istri karena suami memahami keadaan istrinya, serta memahami apa yang diinginkan istrinya. Namun ada juga suami yang belum mendukung keinginan istrinya dalam ber $\mathrm{KB}$ karena dipengaruhi oleh faktor lingkungan, pengetahuan dan agama, dimana faktor pengetahuan suami yang kurang dalam mengetahui manfaat dari kontrasepsi tersebut. (Destyowati, 2012)

Pemahaman suami adalah sumber emosional, informasi atau pendamping untuk menghadapi setiap permasalahan dan krisis yang terjadi sehari-hari dalam kehidupan, pemahaman suami mempunyai hubungan dalam pengambilan keputusan penggunaan alat kontrasepsi. Hal ini dipengaruhi beberapa faktor misalnya kurang pengetahuan suami akan alat kontrasepsi dan pentingnya pemberian dukungan dalam pemilihan alat kontrasepsi, kesibukan suami dalam merealisasikan perannya sebagai kepala keluarga dalam mencari nafkah untuk memenuhi keperluan keluarga. (Figure, 2015)

Alat Kontrasepsi Dalam Rahim (AKDR / IUD) adalah cara pencegahan kehamilan yang sangat efektif, aman dan reversible bagi wanita tertentu terutama yang tidak terjangkit PMS dan pernah melahirkan. IUD terdiri dari dua jenis yakni yang mengandung obat dan tidak mengandung obat. Efektivitas IUD dipengaruhi olehkatakteristik alat, keterampilan penyedia pelayanan dan karakteristik pemakai Sebagian besar ibu tidak menggunakan KB IUD (Everett, 2017)

Sebagian besar suami menyarankan ibu untuk aktif dalam program $\mathrm{KB}$, namun pada dukungan penghargaan sebagian besar suami tidak memberikan semangat untuk 
ibu melakukan program KB. Pada dukungan instrumental lebih banyak suami mengantarkan ibu untuk melakukan KB namun hanya menunggu diluar klinik dan hanya sebagian kecil suami yang mendampingi ibu sampai kedalam ruang praktek bidan. Pada dukungan emosional sebagian besar suami menyakan bagaimana kondisi kesehatan ibu setelah mengikuti program KB, namun sebagian besar suami dalam dukungan emosional tidak mendukung seperti suami tidak pernah mendengarkan keluhan-keluhan yang ibu sampaikan selama ibu aktif di program Keluarga Berencana (KB). Hal tersebut dapat membuat ibu merasa kurang diperhatikan secara emosional oleh suami sehingga dapat mengurangi semangat ibu untuk aktif di program Keluarga Berencana (KB). (Yunitasari, 2011)

Hal tersebut dikarenakan ibu menggunakan $\mathrm{KB}$ yang lebih mudah dalam penggunaan, tidak terlalu beresiko dan keyakinan ibu dalam pemilihan KB selain IUD dapat mencegah kehamilan sesuai dengan yang diharapkan. Hasil penelitian juga menunjukkan terdapat 3\% ibu yang menggunakan KB IUD.Alasan ibu menggunakan KB IUD dikarenakan aman, nyaman, jangka panjang dan untuk mencegah kehamilan lagi. Hal tersebut menunjukkan ibu yang menggunakan KB IUD sudah mengetahui tentang IUD. AKDR adalah suatu alat atau benda yang dimasukkan kedalam Rahim yangsangat efektif, reversibel dan berjangka panjang, dapat dipakai oleh semua perempuan usia reproduksi. AKDR atau IUD atau Spiral adalah salah satu alat yang dimasukkan ke dalam rahim wanita untuk tujuan kontrasepsi.( Fitri, 2012)

Penelitian ini sejalan dengan penelitian yang dilakukan oleh Fitri dkk (2019) dengan judul hubungan dukungan suami dengan keikutsertaan ibu akseptor KB IUD di puskesmas mandiangin kecamatan MKS Di Kota Bukittinggi Tahun 2019, dengan hasil uji statistik didapatkan bahwa ada hubungan Dukungan suami dengan Keikutsertaan KB IUD di Puskesmas Mandiangin Kecamatan MKS Kota Bukittinggi Tahun 2019 dengan p-value $(0,013<0,05)$.

\section{KESIMPULAN}

Berdasarkan hasil penelitian yang telah dilakukan, maka dapat disimpulkan sebagai berikut :

1. Ada Hubungan Pemahaman Suami Terhadap Keikutsertaan Ibu Menjadi Akseptor KB IUD di Kecamatan Secanggang Kabupaten Langkat

2. Ada Hubungan Dukungan Suami Terhadap Keikutsertaan Ibu Menjadi Akseptor KB IUD di Kecamatan Secanggang Kabupaten Langkat

\section{REFERENSI}

Anggara VSP, Rokhanawati D. Hubungan Tingkat Kecemasan Akseptor dengan Pemilihan Kontrasepsi IUD (Intra Uterine Device) di PKD Kamongan Srumbung Magelang. STIKES'Aisyiyah Yogyakarta; 2015.

Destyowati M. Hubungan Tingkat Pengetahuan Ibu Tentang Kontrasepsi IUD Dengan Minat Pemakaian Kontrasepsi IUD Di Des Harjobinangun Kecamatan Grabak Kabupaten Purworejo Tahun 2011. J Komun Kesehat (Edisi 5). 2012;3(2).

Everett S. Buku saku kontrasepsi dan kesehatan seksual reproduktif. Diterjemahkan oleh Nike BS Jakarta EGC. 2017;

Figure S. hubungan antara pengetahuan efek samping alat kontrasepsi dengan kecemasan efek samping pada calon akseptor AKDR Title_2015. 2015;(c):1-4.

Fitri R. Hubungan faktor predisposisi, faktor pemungkin dan faktor penguat dengan pemilihan kontrasepsi IUD. FKM USM. 2012;

Handayani S. Buku ajar pelayanan keluarga berencana. Yogyakarta: Pustaka Rihama. 2016;39.

Koes I. Pelayanan Keluarga Berencana Dua Anak Cukup. Bandung: Alfabeta; 2013.

Fitri Media, dkk Hubungan Dukungan Suami dengan Keikutsertaan Ibu Akseptor KB IUD Di Puskesmas Mandiangin Kec. MKS Di Kota Bukittinggi Tahun 2019 Jurnal Riset Hesti Medan Akper Kesdam I/BB Meda Vol. 5, No. 2, Desember 
2020, pp. 130-135 (2019)

Suherman RM, Widjajanegara H, Yuniarti

L. Hubungan Karakteristik Akseptor dengan Pemilihan Metode Kontrasepsi (Studi di Kecamatan Argapura, Kabupaten Majalengka). In: Bandung Meeting on Global Medicine \& Health (BaMGMH). 2017. p. 99-105.

Yunitasari L. Hubungan Pengetahuan Ibu Tentang alat Kontrasepsi Dengan Pemilihan Kb IUD di Puskesmas Tegal Rejo. 2011; 